\title{
Divino Michelangelo, o Apeles moderno.
}

\author{
Cristiane Maria Rebello Nascimento \\ Departamento de Filosofia - EFLCH \\ Universidade Federal de São Paulo
}

\begin{abstract}
Resumo: Os elogios a Michelangelo produzidos pelos autores do século XVI descrevem-no como o Apeles moderno, dotado de um engenho divino, de um juízo douto na arte, de um temperamento terribile que produziu um obra igualmente terribile e mirabile, tendo por isso se igualado em excelência aos artistas antigos e superado todos os modernos. Examinando os argumentos do gênero do encômio, este artigo pretende demonstrar como no encarecimento destas qualidades artísticas excepcionais no artista é tecida também a amplificação da importância do desenho na prescrição e na prática artística, ao longo do século XVI.
\end{abstract}

Palavras-chave: Michelangelo, encômio, biografia, idea, desenho.

\begin{abstract}
Writers of the 16th Century lavished praise on Michelangelo Buonarotti, describing him as the modern day Apelles of Kos, possessed by an ingenuity approaching the divine, of a temperament imbued with terribilità that brought forth opere likewise terribile and mirabile equaling those of ancient times and ultimately surpassing all modern ones. Through an examination of 16th Century epideictic discourse, this article demonstrates how the enhancement of these exceptional qualities are intrinsically associated with the increasing importance of drawing in artistic practice and the prescriptions that support it.
\end{abstract}

Keywords: Michelangelo, eulogy, biography, idea, disegno.

Como ocorre nos modelos encomiásticos antigos ressuscitados pelos humanistas do século $\mathrm{XV}$, como por exemplo as Vidas Paralelas, de Plutarco e o Elogio a Atenas, de Aelius Aristides, o elogio ao artista tem como gênero principal o biográfico, no qual encontra-se associado ao elogio da cidade, 
ou da pátria. Mas o elogio ao artista não se efetua apenas nas biografias. Trata-se de um topos disseminado nos vários gêneros de escrito de arte produzidos ao longo do século XVI, como é o caso do tratado, do diálogo e das epístolas trocadas entre humanistas e artistas. Nota-se, portanto, que estes escritos partilham o mesmo fim encomiástico-pedagógico da biografia: apresentar o artista com exemplo, ou modelo, o mais perfeito possível, a ser imitado nas obras e nas virtudes.

O discurso encomiástico relativo aos artífices do desenho atinge seu ápice na segunda metade do século XVI com as biografias de artistas florentinos escritas por Giorgio Vasari, assim como na oração fúnebre que o humanista florentino Benedetto Varchi dedica a Michelangelo Buonarroti. Substituindo o gênero do diálogo, que na primeira metade do século XVI passa a ser o gênero preferencial na prescrição da arte, as biografias de artistas colocam definitivamente a figura do artista no panteão dos homens ilustres dignos de elogio, no qual encontram-se já imperadores, condottieri, poetas, e filósofos ${ }^{1}$.

O aspecto retórico-encomiástico dos escritos de arte renascentista, contudo, nem sempre foi compreendido positivamente. A crítica do século XIX e da primeira metade do século XX, pautadas por um total desinteresse por tudo que cheirasse à retórica, atribuiu-lhes o emprego de um vocabulário crítico vagamente retórico, insincero, fantasioso, interpretando-

1 No século XIV, por exemplo, o humanista florentino Gianozzo Manetti escreve várias biografias de homens ilustre, entre os quais encontram-se os poetas florentinos Dante, Francesco Petrarca e Giovanni Boccaccio, assim como os poetas latinos e os filósofos gregos Sócrates e Sêneca. Cf. MANETTI, Gianozzo. Biographical writings, editado e traduzido por Stefano U. Baldassari e Rolf Bagelmihl, The I Tatti Renaissance Library, Harvard University Press, 2003. 
os como teoricamente incoerentes e historicamente imprecisos ${ }^{2}$. Na contramão desta perspectiva, este artigo pretende demonstrar de que maneira os elogios e epítetos conferidos a Michelangelo compõem os preceitos de uma doutrina do desenho.

Os elogios a Michelangelo produzidos pelos autores do século XVI descrevem-no como um novo Apeles ${ }^{3}$, dotado de um engenho divino, de um juízo douto e diligente na arte, de um temperamento terribile que produziu obras igualmente terribili e mirabili, tendo por isso superado em excelência não apenas os artistas antigos, mas também todos os modernos e, por fim, a si próprio, como diz Benedetto Varchi a propósito da pintura do Juízo

2 POZZI, Mario \& MATTIODA, Enrico. Giorgio Vasari. Storico e critico, Firenze, Leo Olschki Editore, 2006, pp. IX-XII. O crítico Gaetano Milanesi escreve, em 1866, que Giorgio Vasari é belíssimo escritor das artes italianas, mas historiador não confiável, e que suas Vite é mais uma recolha de anedotas e fatos menores a respeito das artistas, do que uma narrativa ordenada e confiável. A propósito da suposta incoerência teórica de Vasari, cf. SCHLOSSER MAGNINO, Julius. La letteratura artistica. Manuale delle fonti della storia dell'arte moderna, Firenze, La Nuova Italia, 1996, pp. 322-323.

3 A própósito da doutrina, da beleza e da graça das obras de Apeles cf. PLINIO, O VELHO. Natural History, 35, 79-80: Verum omnes prius genitos futurosque postea superavit Apelles Cous olympiade centesima duodecima. Picturae plura solus prope quam ceteri omnes contulit, voluminibus etiam editis, quae doctrinam eam continent. Praecipua eius in arte venustas fuit, cum eadem aetate maximi pictores essent; quorum opera cum admiraretur, omnibus conlaudatis deesse illam suam venerem dicebat, quam Graeci charis vocant; cetera omnia contigisse, sed hac sola sibi neminem parem, et aliam gloriam usurpavit, cum Protogenis opus inmensi laboris ac curae supra modum anxiae miraretur; dixit enim omnia sibi cum illo paria esse illi meliora, sed uno se praestare, quod manum de tabula sciret tollere, memorabili praecepto nocere saepe nimiam diligentiam. Fuit autem non minoris simplicitatis quam artis. Melanthio dispositione cedebat, Asclepiodoro de mensuris, hoc est quanto quid a quoque distare deberet. 
Final, em sua Oração fúnebre ${ }^{4}$. O encarecimento destas qualidades artísticas excepcionais em Michelangelo está intrinsicamente associado à amplificação da importância do desenho na prescrição e na prática artística, ao longo do século XVI. Numa analogia com o modelo ciceroniano de uma perfeita idea de eloquência a ser imitado pelo orador, o desenho é definido por estes autores tanto como conceito, idea, ou invenção mental elaborada pelo engenho agraciado do artista, quanto como destreza, ou operação de mão, capaz de imitá-la da maneira fidedigna, reduzindo-a uma perfeita obra.

A coroação do artista como o princípe entre os artistas modernos rendeu-lhe quatro biografias escritas ainda em vida: a de Paolo Giovio, de 1527; a do anômino Magliabecchiano, de 1549, no qual um brevíssimo encômio abre um sucinto elenco das obras do artista; a de Ascanio Condivi, de 1553, e as duas versões escritas por Giorgio Vasari, em 1550 e em 1563. Recebeu também uma honraria reservada a pouquíssimos artistas: uma oração fúnebre, proferida por Benedetto Varchi, na Accademia Fiorentina, em 1564; assim como uma exéquia digna de uma homem de estado. Por fim, em 1567, o escultor perugino, Vincenzo Danti escreve o Trattato delle perfette proporzioni, cujos preceitos são tirados das exemplares figuras humanas produzidas por Michelangelo, em desenho, em pintura e em escultura.

Michelangelo é também o principal interlocutor em dois importantes diálogos do século XVI, nos quais prescreve em

4 VARCHI, Benedetto. 'Orazione funerale di Messer Benedetto Varchi fatta, e recitata da lui pubblicamente nell'essequie di Michelagnolo Buonarroti in Firenze nella chiesa di San Lorenzo', Firenze, Giunti, 1564, editada e comentada por Charles Davis, in Quellen und Dokumente zur Kunst 1350-1750, E- Texte, n. 23 http://archiv.ub.uni-heidelberg.de/artdok/volltexte/2008/643, p. 21. 
primeira pessoa a propósito da arte, refiro-me aos Dialoghi de 'giorni che Dante consumo nel cercare l'inferno e l'Purgatorio, escritos pelo humanista Donato Gianotti, em 1549; e os Diálogos em Roma, escritos pelo pintor e tratadista português Francisco de Holanda, também em 1549. Ainda, em várias passagens das três orações que Benedetto Varchi dedica à disputa das artes, Delle maggioranza dell'arte, de 1549, Michelangelo é citado como a autoridade a legitimar a inclusão da pintura e da escultura nas artes liberais, a arbitrar a disputa entre pintura e escultura e, finalmente, a validar o parentesco entre poesia e pintura. Também o poeta Pietro Aretino faz altos elogios ao engenho e à mão de Michelangelo, declarando-o perfeito mestre não apenas na arte da escultura, mas igualmente na pintura e na arquitetura. Nas cartas que envia ao artista, em meios às queixas pelo não cumprimento da promessa em lhe enviar algum desenho de sua mão, e à crítica severa à falta de decoro e impiedade na pintura do Juízo Final, Aretino atribui a Michelangelo um intelecto divino ${ }^{5}$, que superou com a "imensa potência de seu stilo" Apeles, Phidias e Vitrúvio".

5 MICHELANGELO. Carteggio IV, Firenze, S.P.E.S., pp. 90-91, carta de Pietro Aretino a Michelangelo, datada de 20/01,1538: Certamente voi sete persona divina; e perciò chi ragiona di voi, favelline con un dir sopra humano, se non vol far fede de la sua ignoranza, o mentir nel parlarne a la domestica"; carta de Pietro Aretino a Michelangelo, datada de 31/03/1544: "Ma se Vostra Signoria è riverita, mercé del publico grido, fin da quegli che ignorano I miracoli del suo intelletto divino;

6 Idem. Ibidem, pp. 82-84, carta de Pietro Aretino a Michelangelo, datada de 16/09/1537: Gran miracolo che la natura, che non po locar sì alto una cosa che voi non la ritroviate con l'industria, non sappia imprimere ne le opre sue la maestà che tiene in se stessa l'immensa potentia del vostro stile e del vostro scarpello onde chi vede voi non cura di non havere visto Phidia, Apelle et Vitruvio, in cui spirti fur l'ombra del vostro spirto. 
Aexpectativa de parte dos críticos do século XX em encontrar nestes escritos as genuínas ideias artística de Michelangelo encontra aparente respaldo no que dizem os próprios autores. Não há dúvida que estes autores privaram da companhia e mantiveram com ele uma conversação a respeito de temas da arte, contudo, não se pode atribuir uma estrita autoria michelangiana a elas. Tratam-se antes de ideas tomadas dos escritos de retórica e poética antigos, atribuídas ou exemplificadas por Michelangelo, de acordo com o argumento que ninguém pode julgar melhor uma arte do que aquele que a prática e é, portanto, douto nela.

Buscando autorizar a doutrina do desenho nas opiniões e nas obras do moderno Apeles, tanto Francisco Holanda, quanto Ascanio Condivi e Giorgio Vasari alardeam em seus escritos a relação de amizade, ou de dimestichezza, que mantinham com Michelangelo, apresentando-a como prova, ou evidência, da veracidade dos fatos narrados e da autoridade dos preceitos artísticos atribuídos e exemplificados pelo $\operatorname{artista}^{7}$. Ascânio Condivi, que foi um dos poucos discípulos de Michelangelo, inicia o prólogo de sua biografia recordando sua estreita familiaridade com o mestre e reivindicando ter tomado tudo o diz do próprio "vivo oráculo" de Michelangelo:

\begin{abstract}
Desde que Deus, por seu singular benefício, me fez digno não apenas da presença (na qual apenas), mas do amor, da conversação e da estreita familiaridade com Michelangelo Buonarroti, pintor e escultor único; eu conhecedor de tanta graça
\end{abstract}

7 A propósito da relação de "amizade" e "amor" entre artistas e patronos no renascimento cf. KENT, D. Friendship, Love, and trust in Renaissance Florence (The Bernard Berenson lectures at Villa I Tatti, Harvard University Center for Italian Studies), Cambridge-London, I Tatti Harvard University Press, 2009. 
e amador da profissão e da bondade dele, entreguei-me com todo estudo a observar e reunir não somente os preceitos que ele me dava da arte, mas seus ditos, ações e costumes, com tudo o que me parece digno de maravilha, de imitação, ou de louvor em toda a sua vida [...] E se isso [louvor] me ocorre, me contento que não seja por ser bom escritor, mas por ser coletor fiel e diligente dessas coisas, as quais afirmo ter recolhido com sinceridade e têlas retirado com destreza e longa paciência paciência de seu vivo oráculo, e de tê-las confrontado e confirmado com o testemunho dos escritos e de homens de fé. ${ }^{8}$

Condivi alega ainda que foi forçado a acelerar a escritura da parte concernente à vida de Michelangelo, por duas razões. Primeiramente, para corrigir as imprecisões cometidas por alguns escritores que não tendo privado com o artista diziam coisas que jamais ocorreram, deixando de fora outras dignas de nota. Em segundo lugar, para prevenir a injúria de outros que teriam se apropriado do trabalho que ele lhes havia confiado ${ }^{9}$. Condivi se refere à primeira versão da Vita di Michelangelo publicada

8 CONDIVI, Ascanio. Vita di Michelangelo, Roma, De Luca Editore, 1959, p. 101-102.

9 Idem. Ibidem, p. 101-102: E mentre tutte due vi vanno parte moltiplicando e parte digerendo, è nato accidente che per doppia cagione sono forzato d'accelerare, anzi di precipitar quella della Vita. Prima, perchè sono stati alcuni che scrivendo di questo raro uomo, per non averlo (come credo) così praticato come ho fatto io, da un canto l'hanno dette cose che mai non furano, dall'altro lassatene molte di quelle che son dignissime d'esser notate; di poi, perchè alcuni altri, a' quali ho conferite e fidate queste mie fatiche, se l' hanno per modo appropriate, che come di sue disegnano farserne onore. Onde per supplire al difetto di quelli, e prevenir l'ingiuria di questi altri, mi son risolto di darle fuori così immature come le sono. 
por Vasari, em 1550. A hipótese é corroborada pelo fato de que só a partir desta data Giorgio Vasari começa a se corresponder com Michelangelo, produzindo finalmente a prova, ausente na primeira versão da Vida, da veracidade dos fatos narrados pelo "vivo oráculo" de Michelangelo ${ }^{10}$.

Longe de serem insiceros ou incoerentes, os elogios tecidos a Michelangelo pelos autores do século XVI cumprem os argumentos previstos no gênero do encômio, o qual deve revelar a grandeza das ações do homens virtuosos e outras qualidades pertencentes a uma figura particular. O elenco desses argumentos encontra-se nos exercícios retóricos da segunda sofística, os Progymnasmata, nos quais se exercitavam os autores do século XVI.

Aelius Theon, por exemplo, estabelece que o encômio deve referir primeiramente as qualidades externas e internas relativas ao nascimento auspicioso: em que lugar, e de que família nasceu e com que tipo de intelecto, caráter e aparência física. Seguem-se a estas, a educação, as amizades, a fama conquistada, a riqueza, e, no caso de um epitáfio, a boa morte. O encômio deve referir também as virtudes morais, que são aquelas mentais - prudência, temperança, a coragem, a justiça, a piedade, magnanimidade, liberalidade, e, no caso do artista, o engenho -, assim como as ações e as obras resultantes delas. Estas, devem ser elogiadas de acordo com a ocasião em que foram realizadas: se foram realizadas pela primeira vez e sem ajuda de outros; se aquele que a fez trabalhou mais que os outros, ou a fez com pouca ajuda; se ultrapassaram aquelas realizadas antes, ou contrariamente à expectativa de sua

10 A propósito da importância da correspondência direta de Michelangelo na redação das biografias do artistas e, particularmente, na redação das duas versões da biografia de Vasari cf. PARKER, Deborah. Michelangelo and the Art of Letter Writing, Cambridge University Press, 2010, pp. 10-46. 
realização; se foram feitas com ajuda de instrumentos, ou com facilidade, ou velozmente ${ }^{11}$.

O elogio do artista implica, portanto, encarecer nele todas estas qualidades externas e internas elencadas acimas. Mas implica, sobretudo, encarecer a destreza de mão com que executa sua arte, à qual deve operar no mesmo grau de dificuldade das invenções, ou ideias, que o artista concebeu em sua mente, produzindo obras excepcionais.

À exceção de Paolo Giovio, todos os biógrafos cumprem em seus elogios a tópica do encarecimento do nascimento auspicioso de Michelangelo, que foi "mandado à terra por Deus, para dar o última realização e a extrema perfeição às artes mais belas", como diz Bendetto Varchi ${ }^{12}$. Quanto ao caráter, encarecem seu temperamento melancólico, típico dos grandes engenhos, que o fez preferir o amor pela arte e a fama eterna que advém dela, à efemeridade da vida mundana. A exemplo do antigo Apeles, cuja prática diária da arte tornou-se proverbial ${ }^{13}$, Michelangelo é retratado como diligente e estudioso, douto na arte, perfeito na invenção e no desenho, superando por isso todos os artistas que vieram antes dele, antigos e modernos.

11 PROGYMNASMATA. Greek textbooks of prose composition and Rhetoric, tradução, introdução e notas de George A. Kennedy, Atlanta, Society of Biblical Literature, 2002, pp. 50-52.

12 VARCHI. 'Orazione funerale', p. 11: il perche non solamente potemo credere, ma devemo risolutamente tenere nobilissimi, e religiossimi Ascoltatori MICHELAGNOLO essere stato eletto in cielo, e mandato in terra da DIO, per dare l'ultimo compimento, l'ultima perfezzione alle tre arti piu belle.

13 PLINIO, O VELHO. Ibidem, 84: Apelli fuit alioqui perpetua consuetudo nunquam tam occupatum diem agendi, ut non lineam ducendo exerceret artem, quod ab eo in proverbium venit. 
A primeira biografia dedicada a Michelangelo, aquela escrita por Paolo Giovio, em 1527, em conjunto com as biografias de Leonardo da Vinci e Rafael Sanzio, estabelece os argumentos centrais que serão desenvolvidos nos encômios posteriores. Neste conjunto de biografias, Giovio elogia as virtudes e os feitos da tríade dos engenhos que reconduzirão as artes do desenho a uma nova excelência. Essa nova excelência, que Giorgio Vasari chamará mais tarde de maniera moderna, caracteriza-se por restituir à arte a regra, a ordem, a medida, o desenho e a maneira parecida ao verdadeiro, e por força de imitar as coisas belas, por ter se tornado efetivamente mais bela que as maneiras anteriores ${ }^{14}$.

A primeira das biografia de Giovio é dedicada a Leonardo da Vinci, o mais velho dos três artistas. Giovio atribui a ele o estabelecimento de algumas regras, ou preceitos, fundamentais na imitação pictórica, como a da necessidade de o pintor dominar as várias ciências e artes liberais necessárias à pintura (recomendações que Cícero e Quintiliano fazem ao orador); a de que o pintor deveria começar seus estudos imitando as obras plásticas e só depois passar às obras pictóricas, para aprender a representar o relevo no plano; e, finalmente, a da importância das

14 VASARI, Giorgio. Vite dei più eccellenti pittori, scultori e architetti (edizione Giuntina, 1568), Roma, Newton, 1991, proemio, pp-553: Veramente grande augumento fecero alle arti della architettura, pittura e scultura quelli eccellenti Maestri che noi abbiamo descritti sin qui, nella Seconda Parte di queste Vite; aggiugnendo alle cose de' primi regola, ordine, misura, disegno e maniera se non in tutto perfettamente, tanto almanco vicino al vero, che $\mathrm{i}$ terzi, di chi noi ragioneremo da qui avanti, poterono mediante quel lume sollevarsi e condursi alla somma perfezzione, dve abbiamo le cose moderne di maggior preggio e più celebrate (...) la maniera venne poi la più bella, dall'avere messo in uso il frequente ritrarre le cose più belle; e da quel più bello, o mani o teste o corpi o gambe aggiugnerle insieme e fare una figura di tutte bellezze che più si poteva; e metterla. 
regras da ótica na observação da leis das luzes e das sombras e dos estudos anatômicos. Giovio, contudo, recrimina em Leonardo o vício da excessiva meticulosidade na busca de meios e técnicas refinadas, assim como o juízo vulnerável que lhe fazia alterar continuamente suas primeiras ideias, ou invenções, impedindolhe de terminar suas obras. Seu temperamento, elogia Giovio, era afável, brilhante e generoso; sua face era bela; era dotado das qualidades do cortesão, sabendo cantar e tocar harpa, sendo, por essa razão, acolhido por todos os príncipes de seu tempo.

A terceira biografia é dedicada a Rafael Sanzio, em virtude da "maravilhosa doçura e habilidade de um engenho pronto a assimilar" as invenções de outros mestres. Assim como no caso de Leonardo, Giovio atribui a fama e a intimidade que Rafael cultivou entre os homens potentes, não apenas à excelência de suas obras, mas também à cortesania e à civilidade que caracteriza seu comportamento. A qualidade distintiva que Giovio atribui as suas obras é análoga àquela que caracteriza seu comportamento, "uma beleza particular que chamamos "graça". Entretanto, considera que Rafael tendesse, por vezes, a antepor a força da arte à natureza, ressaltando de maneira excessiva os músculos dos membros. Embora tivesse pouco domínio das regras da perspectiva, Giovio atribui-lhe uma habilidade que faltava a Michelangelo: "saber unir à pintura bem desenhada o ornamento luminoso e resistente das cores da pintura a ólio", adocicando e fundindo a aspereza das cores muito vivas.

Mas é a Michelangelo que Giovio concede a palma de melhor artista, porque foi reconhecido pelo juízo dos demais artistas como aquele que mais se aproximou da excelência dos 
artistas antigos, tanto no pintar, quanto no esculpir figuras ${ }^{15}$. Giovio, contudo, opõe à perfeição da arte de Michelangelo uma dura crítica ao seu caráter "rude" e "selvagem" que, na sua opinião, teria tornado sua vida doméstica sórdida e privado a posteridade de discípulos que continuassem a sua arte. Mesmo diante do apelo de príncipes, diz Giovio, Michelangelo jamais aceitou ser mestre de outros artistas, e nem mesmo admitia a presença deles em seu ateliê $\hat{e}^{16}$. Essa recriminação ao caráter de Michelangelo será, contudo, reinterpretada nos encômios posteriores como uma virtude artística típica dos engenhos excepcionais. $\mathrm{O}$ caráter selvagem que o levou a não ter discípulos e não delegar a execução a outros artistas não apenas é um argumento que faz acrescer a grandiosidade de seus feitos artísticos, mas revela também seu "engenho peregrino", o qual, diz Bendetto Varchi, não deve perder tempo em ensinar pessoas particulares, como um mestre que vende sua ciência por minuto, porque com suas obras "aprenderam, aprendem e aprenderão os melhores mestres de seu tempo"17.

15 GIOVIO, P. Michaelis Angeli Vita, in BAROCCHI, Paola. Scritti d'arte del Cinquecento, tomo I, Milano/Napoli, Riccardo Ricciardi, 1971, p. 10: In pictura pariter scalpendoque marmore Michael Angelus Bonarota Etruscus priscorum artificum dignitati proximus accessit, adeo aecquabili fama iudicioque omnium, ut utriusque artis viri insignes meritam ei palmam ingenua confessione detulerint.

16 Idem. Ibidem, p. 12: Caeterum tanti ingenii vir natura adeo agrestis ac ferus exitit ut supra incredibiles domesticae vitae sordes successores in arte posteris inviderit. Nam vel obsecratus a principibus numquam adduci potuit, ut quemquam doceret vel gratia spectandi saltem in officinam admitteret.

17 Varchi. 'Orazione funerale', pp. 34-35: Percioche, quanto al non volere insegnare, non havemo noi mostrato, poco fa, che prima da un suo cartone solo impararono tutti I migliore Maestri del suo tempo [...] Non può uno'ngegno pellegrino, e che ha sempre l'intelletto intento à cose divine, ne forse dee; 
Em relação às obras, Giovio encarece a dificuldade e a presteza com que o artista executou a pintura do teto da Capela Sistina. Embora, diz o autor, Michelangelo tenha sido obrigado a trabalhar inclinado, ou seja, numa posição de extrema dificultação, o artista não deixou de dar relevo aos corpos planos e de fazêlos parecer sólidos, enganando assim o mais severo de todos os juízos, o dos artistas entendidos ${ }^{18}$ :

Chamado por Júlio II no Vaticano com a oferta de um enorme pagamento, realizou em breve tempo uma obra imensa, deixando na Capela Sistina o testemunho de uma arte perfeita. Embora obrigado a pintar inclinado, afastou e quase escondeu algumas figuras em recessos onde a luz se degradava pouco a pouco, como o tronco de Holofernes na tenda, mas em outros, como em Aman crucifixo, exaltou com tanta felicidade a própria luz, mediante o contraste das sombras, que até os artistas mais conhecedores foram induzidos, para espanto deles, a perceber

spendere il tempo, che vola si rattamente; non voglio dire perdere, per insegnare ò à uno, ò à due particolarmente; e non vo dir vendere, ma donare la sua scinza à minuto.

18 Certamente, Giovio alude aqui à conhecidíssima anedota narrada por Plínio, o velho, a propósito da disputa entre Zeuxis e Parrásio, que elogia o aspecto ilusionístico da pintura. A anedota conta que enquanto as uvas pintadas por Zeuxis enganou os pássaros que vinham bicá-las, a cortina pintada por Parrásio enganou os olhos experientes de Zeuzis, o qual pediu a Parrásio que a abrisse para que pudesse ver o que estava pintado atrás dela. Cf. PLINIO, O VELHO. Natural History, XXXV, 65-66: "descendisse hic in certamen cum Zeuxide traditur et, cum ille detulisset uvas pictas tanto successu, ut in scaenam aves advolarent, ipse detulisse linteum pictum ita veritate repraesentata, ut Zeuxis alitum iudicum tumens flagitaret remoto linteo ostendi picturam atque intellectto errore concederet palmam ingenuo pudore, quoniam ipse volucres fefellisset, Parrhasius autem se artificem". 
como sólidos, pela verdade da representação, corpos que eram com efeito planos. Entre as mais importantes figuras de homem está no centro da volta aquele de um velho que voa no céu, desenhado com tanta simetria que quem o olha de pontos diversos da capela parece, por ilusão ótica, sempre girar-se e mudar o próprio gesto ${ }^{19}$

Este elogio é de extrema importância para os encômios posteriores porque estabelece como evidência da perfeição de sua arte uma obra pictórica, sendo ele reconhecido até então apenas como escultor. $\mathrm{O}$ elogio de Giovio à dificuldade da realização do escorço, que é uma redução prospectica dificultosa, e do relevo nas figuras pintadas no teto da Sistina, é amplificado pela inexperiência de Michelangelo na pintura, e pelas condições adversas de sua execução. Igualmente em outras obras do artista assinala-se uma dificultação técnica que põe à prova seu engenho e sua destreza de mão. A estátua de David é outro exemplo paradigmático de dificuldade apresentado por Giovio. Neste caso, Michelangelo teve que demonstrar extremo engenho e destreza para corrigir um bloco de mármore já desbastado e abandonado por um artista anterior pouco hábil.

19 GIOVIO. Ibidem, pp.10-11: In Vaticano Xistini sacelli cameram a Iulio secundo ingenti pecunia accitus, immenso opere brevi perfecto, absolutae artis tertimonium deposuit. Quum resupinus, uti necesse erat, pingeret, aliqua in abscessus et sinus refugiente sensim limine condidit, ut Olophernis truncum in conopeo, aliquibus autem, sicuti in Hamano cruci affixo, lucem ipsam experimentibus umbris adeo feliciter protulit, ut rapraesentata corporum veritate, ingeniosi etiam artifices, quae plana essent, veluti solida mirarentur. Videre est inter praecipuas virorum imagines media in testudine simulachrum volantis in coelum senis, tanta symmetria delineatum, ut si e diversis sacelli partibus spectetur, convolvi semper gestumque mutare deceptis oculis videatur. 
A dificuldade é a marca distintiva da maneira terribile de Michelangelo, não porque fosse aparente, mas porque dissimulada pela execução veloz que resultava numa aparente facilidade repleta de graça. Vasari diz, no proêmio da terceira parte de suas Vite, que o divino Michelangelo com "uma graça inteiramente graciosa, e uma absoluta perfeição, alcançada com a dificuldade tão fácil de sua maneira", superou em perfeição, nas três artes, tantos os artistas antigos, quantos os modernos:

Mas aquele que entre os mortos e os vivos carrega a palma, transcende e encobre todos é o divino Michelangelo Buonarroti, que não apenas tem o principado de uma destas artes, mas de todas as três conjuntamente. Este supera e vence não apenas todos aqueles que quase venceram a natureza, mas também aqueles famosíssimos antigos, que com tanto louvor, sem dúvida alguma, a superaram: único, triunfa sobre os que venceram a natureza, sobre os antigos e sobre a própria natureza, não se podendo imaginar coisa alguma tão estranha e difícil que com a virtude de seu divino engenho, mediante a indústria, o desenho, a arte, o juízo e a graça, não pudesse ultrapassar de longe. ${ }^{20}$

Como aponta David Summers, no livro Michelangelo and the language of Art, entre os termos empregados pelos autores do século XVI para elogiar os artistas, nenhum é mais frequente e importante que o da dificuldade, que resulta em obras terribili $i^{21}$, em particular, naquelas cujo tema é igualmente terribile, como

20 VASARI. Vite (edizione Giuntina, 1568), pp. 555-556.

21 SUMMERS, David. Michelangelo and the language of Art, Princeton, Princeton University Press, 1981, pp. 177-185. 
fica evidente no elogio ecfrástico que Giorgio Vasari faz à estátua de bronze de Júlio II, cujo temperamento é terribile, e também à pintura do Juízo Final ${ }^{22}$. Até Paolo Pino, que prefere a maneira doce de Rafael às figuras dificultosas de Michelangelo, no tratado Dialogo di Pittura, escrito em 1548, recomenda ao pintor colocar na composição ao menos uma figura "recursada, misteriosa e difícil", como prova da habilidade a ser reconhecida por quem entende a perfeição da arte" ${ }^{23}$.

Já Quintiliano aconselhava ao orador alguma demonstração de dificuldade no discurso, uma vez que ela traz consigo um efeito de novidade que deleita e evidencia o domínio técnico do orador. Quintiliano ilustra esse recurso retórico numa pintura que imita com graça e vivacidade as suas figuras, por meio da variedade nas vestes, nas poses e na expressão dos rostos ${ }^{24}$. Mas, como se disse

22 BAMBACH, Carmen C. "Vasari on Michelangelo's "Gelosie delle Figure" and the destruction of his drawings', in Annali Aretini XX, Edizioni Fraternità dei Laici Arezzo, 2012, p. 141.

23 PINO, Paolo. Dialogo di Pittura (1548), in BAROCCHI, Paola. Scritti d'arte del cinquecento, I, Milano/Napoli, Riccardo Ricciardi, 1971, p. 761: "et in tutte l'opere vostre fateli intervenire almeno una figura tutta sforciata, misteriosa e difficile, acciò che quella voi siate notato valente da chi intende la perfezzion dell'arte".

24 QUINTILIANO. Institutio Oratoria, II, XIII, 8-10: Expedit autem saepe mutare ex illo constituto traditoque ordine aliqua et interim decet, ut statuis atque picturis videmus variari habitus, vultus, status. Nam recti quidem corporis vel minima gratia est; nempe enim adversa sit facies et dimissa brachia et iuncti pedes et a summis ad ima rigens opus. Flexus ille et, ut sic dixerim, motus dat actum quendam et adfectum. Ideo nec ad unum modum formatae manus et in vultu mille species. Cursum habent quaedam et impetum, sedent alia vel incumbunt; nuda haec, illa velata sunt, quaedam mixta ex utroque. Quid tam distortum et elaboratum quam est ille discobolos Myronis? Si quis tamen, ut parum rectum, improbet opus, nonne ab intellectu artis abfuerit, in qua vel praecipue laudabilis est ipsa illa novitas ac difficultas? 
acima, a dificuldade não deve ser evidente, deve ao contrário mostrar-se como aparente facilidade que dissimula as marca da operosidade do artista e acrescenta beleza e graça às obras.

$\mathrm{O}$ elogio à perfeição de Michelangelo em artes que exigem competências técnicas muito diversas, como é o caso da pintura e da escultura, justifica-se no domínio que artista tem do desenho, onde reside toda a doutrina da arte. É a prática do desenho, que Vasari chama de "verdadeiro lume [...], que faz os homens excelentes" 25 , que permite que o artista exprima, ou declare o conceito, ideia, ou invenção que traz na mente.

A opinião expressa por Michelangelo a respeito da disputa entre pintura e escultura elaborada por Benedetto Varchi, conhecida como o paragone das artes, vai de encontro ao esforço encomiástico dos autores do século XVI em transformá-lo na personificação da doutrina do desenho. $\mathrm{Na}$ carta que envia a Benedetto Varchi, datada de 31 de março de 1547, respondendo às demandas do humanista para que expressasse sua opinião a propósito de qual arte fosse melhor, a pintura, ou a escultura, Michelangelo diz que

a pintura [lhe] parece tanto melhor quanto mais se aproxima do relevo, e este tanto pior quanto mais próximo da pintura, embora costumasse [lhe] parecer que a escultura fosse a lanterna da pintura, e que de uma a outra houvesse a distância que há entre o sol e a lua. Mas, depois que li seu libreto onde diz, que falando filosoficamente, que aquelas coisas que tem o mesmo fim são uma mesma coisa, mudei de opinião e digo que, se maior juízo, dificuldade, impedimento e fadiga não resultam em

25 VASARI. Vite (edizione Giuntina, 1568), p. 74. 
maior nobreza, então pintura e escultura são uma mesma coisa. E porque é tida assim, nenhum pintor deveria praticar menos a escultura que a pintura, e, igualmente, o escultor a pintura do que escultura. ${ }^{26}$

Mais importante que insistir na proverbial agudeza do artista na mudança de opinião alardeada diante da lição filosófica de Benedetto Varchi, - agudeza esta que lhe teria custado na juventude a deformidade do nariz quebrado pelo altivo e invejoso

26 MICHELANGELO. Carteggio, IV, 1979, p. 265-266: Messer Benedecto, perché e' paia pur che io abbia ricievuto, com'io ò, il vostro Librecto, risponderò qualche cosa a quel che e' mi domanda, benché igniorantemente. Io dico che la pictura mi par più tenuta buona quante più va verso il rilievo, e el rilievo più tenuto cactivo, quante più va verso la pictura però a me soleva parere che la scultura fussi la lanterna della pictura, e che da l'una a l'altra fussi quella diferentia che è dal sole a la luna. Ora, poi che io ò lecto nel vostro Librecto dove dite che, parlando filosoficamente, quelle cose che ànno un medesimo fine sono una medesima cosa, io mi son mutato d'openione e dico che, se maggiore $\mathrm{g}[\mathrm{i}]$ udicio e dificultà, impedimento e fatica non fa maggiore nobilità, che la pictura e scultura è una medesima cosa; e perché la fussi tenuta così, non doverrebbe ogni pictore far manco di scultura che di pictura e ' 1 simile lo scultore di pictura che di scultura. Io intendo scultura quella che si fa per forza di levare; quella che si fa per via di porre è simile a la pictura. Basta, che, venendo l'una e l'altra da una medesima intelligentia, cioè scultura e pictura, si può far far loro una buona pace insieme e lasciar tante dispute; perché vi va più tempo che a far le figure. Colui che scrisse che la pictura era più nobile della scultura, se gli avessi così bene intese l'altre cose che gli à scricte, l'arebbe meglio scricte la mie fante. Infinite cose, e non più decte, ci sare' da dire di simile scientie; ma, come ho decto, vorrebon troppo tempo, e io n'ò poco, perché non solo son vechio, ma quasi nel numero de' morti. Però prego m'abbiate per iscusato. E a voi mi rachomando e vi ringratio quanto so e posso del troppo onor che mi fate, et non conveniente a me.Vostro Michelagniolo Buonarroti in Roma. 
Pietro Torrigiani ${ }^{27}$, e com a qual teria rebatido as críticas de Pietro Aretino à sua falta de decoro por não ter coberto as partes pudendas dos anjos e dos santos, na pintura do Juízo Final ${ }^{28}$-, é reconhecer que Michelangelo foi o único entre os pintores e escultores a quem Varchi colocou a mesma questão, a admitir a

27 VASARI. Vite (edizione Giuntina, 1568), 'Vita di Torrigiano, scultor fiorentino', pp. 605-608.

28 A crítica de Pietro Aretino à falta de pudor e à impiedade de Michelangelo no afresco do Juízo Final encontra-se na carta datada de 31 de novembro 1545. Cf. MICHELANGELO. Carteggio, IV, 1979, pp. 215-217: Signor mio. Nel rivedere lo schizzo intiero di tutto il vostro dì del Giudicio, ho fornito di conoscere la illustre gatia di Raffaello ne la grata bellezza de la inventione. Intantio io, come battezzato, mi vergogno de la licentia, sì illecita a la spirito, che avete preso ne lo isprimere I concetti u'si risolve il fine al quale aspira ogni senso de la veracissima credenza nostra. Adunque quel Michelognolo stupendo in la fama, quel Michelognolo notabile in la prudentia, quel Michelognolo ammiranno nei costumi ha voluto mostrare a le genti non meno impietà di irreligione che perfettion di costumi? È possibile che voi, che per essere divino non degnate il consortio degli huomini. Haviate ciò fatto nel maggiore tempio di Dio? Sopra il primo altare di Giesù? Ne la più grande capella del mondo, dove I gran Cardini de la Chiesa, dove i Sacerdoti reverendi, dove il Vicario di Christo con cerimonie catholiche, con ordini sacri e con orationi divine confessano, contemplano et adorano il suo corpo, il suo sangue e la sua carne? Se non fusse cosa nefanda lo introdurre de la similitudine, mi vanterei di bontade nel trattato de la Nanna, proponendo il savio mio avedimento a la indiscreta vostra conscienza, avengaché io in materia lasciva et impudica non pure uso parole avertite e costumate, ma favello con detti irreprensibili et casti; et voi nel suggetto di sì alta historia mostrate gli angeli e i santi, questa senza veruna terrana honestà, e quegli privi d'ogni celeste ornamento. Ecco, i Gentili ne lo iscolpire, non dico Diana vestita, ma nel formare Venere ignuda, la fanno ricoprire con la mano le parti che non si scoprono; et chi pur è christiano, per più stimare l'arte che la fede, tine per reale ispettacolo tanto il decoro non osservatonei martiri e ne le vergini, quanto il gesto del rapito per i membri genitali, che anco serrarebbe gli occhi il postribolo, per non mirarlo. In un bogno delitioso, non in un choro supremo se conveniva il far vostro!... 
resolução filosófica da comparação proposta pelo humanista, que elege o desenho como a parte mais importante da doutrina da arte. A resposta de Michelangelo, longe de configurar um atraso teórico em relação às opiniões artísticas de Leonardo da Vinci, como diz Lionello Venturi ${ }^{29}$, corrobora o elogio que os escritos coevos lhe faziam: o de que a excelência de seu engenho e de sua mão manifestavam-se no perfeito entendimento que tinha do desenho, princípio unificador de todas artes, lugar da perfeita invenção do que será executado posteriormente em pintura, em escultura, e em arquitetura.

É com o elogio de seu perfeito entendimento do desenho que Vasari inicia as duas versões da biografia de Michelangelo:

Enquanto os industriosos e egrégios espíritos, com o lume do famosíssimo Giotto e de seus seguidores, se esforçavam em dar ciência ao mundo do valor que a bondade das estrelas e a proporcionada mistura dos humores tinha dado a seus engenhos, e, desejosos de imitar com a excelência da arte a grandeza da natureza, para alcançar o mais que podiam aquela suma cognição que muitos chamam de inteligência, universalmente, ainda que em vão, se afadigaram, o benigno Retor do céu voltou os olhos clementes à terra, e vista a vã infinidade de tantas fadigas, os ardentíssimos estudos sem fruto e a opinião presunçosa dos homens, mais distante da verdade do que as trevas da luz, para nos retirar de tantos erros se dispôs a mandar à terra um espírito que universalmente, em cada uma das artes e em todas as profissões fosse hábil, operando sozinho para mostrar que coisa seja a perfeição da arte do desenho no traçar, contornar sombrear,

29 VENTURI, Lionello. História da crítica de arte, Lisboa, Edições 70, 2007, pp. 97-98. 
iluminar, para dar relevo às coisas da pintura, e com reto juízo operar na escultura e tornar as habitações cômodas e seguras, sãs, alegres, proporcionadas e ricas de vários ornamentos na arquitetura. ${ }^{30}$

Dentre os escritos citados, o tratado de Francisco de Holanda é o que formula de maneira mais clara como no desenho, que é a primeira obra visível onde reside a força da pintura, funde-se a operação mental e operação manual do artista. No capítulo XVI, do livro primeiro do tratado Da Pintura Antiga Holanda diz:

logo que a idea está determinada e escolhida, como se quer por em obra, far-se ha e por-se ha logo em Desenho, e primeiro que se este faça inda em sua perfeição, se faz o esquizo, ou modello d'ella. Esquizo são as primeiras linhas ou traços que se fazem com a pena, ou com o carvão, dados em grande mestria e depressa, os quaes traços comprendem a idea e invenção do que queremos fazer, e ordenão o desenho, mas são linhas imperfeitas e endeterminadas, nas quaes se busca e acha o desenho e aquillo que é nossa tenção fazermos. Assim que do esquizo se vem a fazer e a compôr o desenho ou debuxo, limando-o e ajuntando-o pouco a pouco, o qual desenho, como digo, tem toda a sustancia e ossos da pintura, antes é a mesma pintura porque n'elle está ajuntado a idea ou invenção, a proporção ou symetria, o decoro ou decencia, a graça e a venustidade, a compartição e a fermosura das quaes é formada esta sciencia. ${ }^{31}$

30 VASARI. Vite (edizione Giuntina, 1568), 'Vita di Michelagnolo Buonarroti', p. 1201.

31 HOLANDA, Francisco. Da Pintura Antiga, introdução e notas Angel 
O desenho, portanto, é para Holanda a primeira obra visível da imagem, ideia, ou invenção que

o pintor viu em seu entendimento com olhos interiores, em grandissimo silêncio e segredo, a qual ha de imaginar e escolher a mais rara e eicelente que sua imaginação e prudência puder alcançar, como um exemplo sonhado, ou visto em o ceo ou em outra parte, o qual ha de seguir e querer depois arremedar e mostrar fóra com a obra de suas mãos propriamente. Esta idea é maravilhosa nos grandes entendimentos e engenhos, e às vezes é tal, que não ha mão nem saber que a possa emitar nem igoalarse com ella. ${ }^{32}$

Essa definição neoplatonizante da operação imitativa do artista é tomada da passagem do Orator, conhecida pelos autores do século XVI, na qual Cícero, afirmando não existir um orador perfeito, compõe seu retrato a partir de uma perfeita ideia da oratória:

ao delinear o perfeito orador retratarei um que talvez jamais tenha existido. De fato, não estou investigando quem seja o perfeito orador, mas qual é a idea insuperável dele que raramente aparece ao longo de um discurso, mas brilha algumas vezes e em alguns lugares, mais frequentemente em alguns oradores, mais raramente em outros. Tenho a firme opinião de que não existiu nada tão belo que não possa ser excedido pela beleza do modelo de que é cópia, assim como a retrato é cópia da face. Essa ideia não pode

González-Garcia, Lisboa, Imprensa Nacional-Casa da Moeda, 1983, p. 98-99. 32 Idem. Ibidem, p. 95-96. 
ser percebida pelo olho, pelo ouvido, ou por nenhum outro sentido; podemos conhecê-la apenas na mente e na imaginação. ${ }^{33}$

Na imitação, diz Cícero, o orador deve seguir o exemplo do escultor Fídias quando esculpiu as estátuas dos deuses:

Seguramente, o escultor quando fez a imagem de Jupiter ou Minerva, não olhou para alguém que servisse de modelo, mas em sua própria mente residia uma idéia de beleza superior; foi para ela que ele dirigiu o olhar e absorto nela deixou que guiasse sua mão de artista para produzir a imagem do deus. Assim como há algo perfeito e excelente no caso da pintura e da escultura - um conceito que guia a imitação do artista na representação dos objetos que não são visíveis aos olhos -, da mesma maneira concebemos em nossa mente a ideia da perfeita eloquência, que com nossos ouvidos captamos apenas a cópia. Estas formas das coisas são chamadas ideas por Platão, autor eminente e mestre na eloquência e no entendimento. ${ }^{34}$

Não é inverossímil pensar que a amplificação da importância da invenção e, consequentemente, do desenho no discurso e na prática artística de meados do século XVI tenha justificado a destruição sistemática que Michelangelo fazia dos próprios desenhos. Há ao menos duas referências claras desta prática ao longo da vida do artista. A primeira é a carta enviada de Roma,

33 CICERO. Orator, translated by G. L. Hendrickson e H. M. Hubbell, Loeb Classical Library, Cambridge-London, Harvard University Press, 1939, II, 7-8. 34 Idem. Ibidem, II, 8 - III, 11. 
em 05 de fevereiro de 1518, pelo ajudante do Michelangelo, Leonardo Sellaio, prestando contas ao artista pelo comprimento de suas instruções para que certos desenhos, ou cartões, fossem queimados ${ }^{35}$. A outra referência se encontra na última carta que o poeta Pietro Aretino envia a Michelangelo, em 31 de março de 1549. Nesta carta, Aretino reitera o desejo de ter algum desenho de Michelangelo e queixa-se da avareza do artista - a mesma avareza à qual Giovio atribuia-lhe a falta de discípulos e à qual Holanda reinterpreta como característica típica de seu engenho inspirado -, que prefere entregá-los prodigamente ao fogo a lhe conceder um deles ${ }^{36}$. Também Francisco de Holanda, numa carta

35 MiCHELANGELO. Carteggio, I, 1965, p. 318: Carisimo Michelagnolo, salute et cet. L'aportatore di questa sarà un mio nipote, al quale, parendovi, darete quella fighura, e lui me la manderà; e nonne arete tanto fastidio, restandovi ubrighato. Piero se ne venne; sarà arivato. Lasc[i]ò le chiave al zio; chon faticha l'ò avute. Sono stato a chasa. È suto portato via quanto legname v'era; bene chredo sia chon vostro chonsentimento, pure ve ne aviso. E' dichono avere arssii tutti que' chartoni, ma non chredo di tutti. Doghomi, ma la volontà vostra s'à a eseguire, e io per piacervi meterei del mio sangue. Perché non mi pare stia a proposito dua tenghino le chiave di chasa, per la gelosia di quelle fighure, parendovi, darò loro tutte le chiave, c[i]oè di sotto. Sì che rispondetemi la volontà vostra.Richordovi solecitare. E se voi vi fermassi a Pisa, mi parebe di mandarvi queste robe, perché n'arete di bisogno per gharzoni, masime di letti; e per mare chosterà pocho a mandalle, disegnato dove volete fermarvi. Avisate quelo volete fac[i]a, e tanto farò, ché nonn ò altro disidero che piacervi. Dominicho non m'à detto nulla de' chasi vostri, chome se mai nonne avesi praticho niente di facende secho. Pier Francesco vi si rachomanda; e io vi richordo, nonne avendo a fare e' libro delle misure della fac[i]ata, mi faciate quello schizo m'avete promesso. A voi mi rachomando e ofero la roba e lla vita metere' per voi, ché nonn ò al mondo altro disidero che servirvi.Vostro Lionardo in Roma. Domino Michelagnolo schultore in Firenze. 36 Idem. Ibidem, IV, 1979, p. 238: Al Buonoaruoti. Signor Michielagnolo, lo Anselmi messer Antonio, veramente lingua della vostra laude et anima de 
datada de 15 de agosto de 1553, pede que Michelangelo lhe envie algum desenho, ainda que fosse apenas uma linha como aquela traçada pelo antigo Apeles, em memória das obras imortais realizadas por ele e como sinal de sua boa saúde e recordação da antiga amizade entre eles ${ }^{37}$. Holanda se refere aqui à competição

la mia affettione, oltra il farvi riverentia in nome di me che vi adoro, scuserà né più né meno la importunità ch'io vi uso per il desiderio estremo d'alcuno disegno di quegli di che sete così prodigo al fuoco, et a me tanto avaro. State sano. Di aprile, in Vinetia, MDXLVI.Pietro Aretino.

37 Idem. Ibidem, V, 1983, pp. 9-10: Molto magnifico signore, il grande dono che Dio ci concede de la vita non è ragion che noi lo perdiamo; ma da poi da rendergli per ciò inefabili gratie, è conveniente che noi lo recuperemo, con saper di quelli che honorevolmente vivono, come è Vostra Signoria. Et anchor che le continue fatichi e dissaggi dil pasato me hanno tolto ogni estudio e recordatione, non hanno potutto torme tuta via la buona memoria de la Signoria Vostra e il domandar sempre novelle de la sanità e vita sua, che a me pur sonno sì chare come a tutti gli soi più chari amichi; e penso io che in tutte quegli cose che dal sommo Idio vengono a la Signoria Vostra, che anchor in quele me fa a me infinita gracia e gli sonno io obligato. Et per non perder questa amicitia ho voluto scriver questa, acciò che mi facia intendere a pieno come si ritrova adesso, in questi filici giorni de sua vech[i]eza, ove io penso che lui non si exercita in manco lodevole opere de buoni esempi de heroica vertù, che quele che fanno le sue mani de imortale lodi ne l'arte de la pittura. Et per il grande amore che io tengo a le cose rare, maxime a le de Vostra Signoria del tempo che io fui in Roma, gli prego che de sua mano mi faccia gratia di mandarme alcun desegno, in memoria de le opere sue, anchora che più non sia che qualque linia o profilo, come de l'antico Apelle, acciò che me sia un vero segno de la sanità de la Signoria Vostra et etiandio una ferma recordati[o]ne di nostra amicitia. Prego a Vostra Signoria mi rescriva et mi faccia intendere si è pur vivo messer Lattantio Tolomei, mio grande patrone e carissimo amico vostro. Il sommo et immortale Dio conserve la Signoria Vostra molti anni, acciò che, da po' questo noioso corso de la vita, le dia sua perfetta pace e nel cielo. Mio patre Antonio d'Olanda si racomanda a la Signoria Vostra con esso me ensieme. De Lixbona, xv d'agosto 1553. Vostro Francesco d'Olanda.Al molto magnifico segnor messer Micael Agnello patrone mio observandissimo. 
entre Apeles e Protógenes, narrada por Plínio, o velho, através da qual alude não apenas ao juízo generoso de Michelangelo em relação às qualidades artísticas de Holanda, à semelhança daquele que Apeles tinha por Protógenes, mas também àquelas do próprio Michelangelo, evidentes já num simples traço executado por ele ${ }^{38}$.

Na opinião de Michael Hirst, que estudou cuidadosamente o conjunto de desenhos do artista, Michelangelo era cioso de suas invenções e procurava evitar que estas lhe fossem "roubadas", vale dizer, imitadas por outros artistas ${ }^{39}$. Preocupação semelhante é recorrentemente expressa pelos autores do período, que justificam a pressa em publicar suas obras, ainda que inacabadas e imperfeitas, para poder corrigir as deturpações que suas ideias, ou invenções, sofreram em mãos alheias. Contudo, o esforço do artista em proteger a novidade de suas invenções não refreou a avidez dos artistas em imitá-las e até Rafael, como afirma Giovio,

38 PLINIO, O VELHO. Ibidem, 81-83: Scitum inter Protogenen et eum quod accidit. Ille Rhodi vivebat, quo cum Apelles adnavigasset, avidus cognoscendi opera eius fama tantum sibi cogniti, continuo officinam petiit. Aberat ipse, sed tabulam amplae magnitudinis in machina aptatam una custodiebat anus. Haec foris esse Protogenen respondit interrogavitque, a quo quaesitum diceret. ' $a b$ hoc', inquit Apelles adreptoque penicillo lineam ex colore duxit summae tenuitatis per tabulam. Et reverso Protogeni quae gesta erant anus indicavit. Ferunt artificem protinus contemplatum subtilitatem dixisse Apellen venisse, non cadere in alium tam absolutum opus; ipsumque alio colore tenuiorem lineam in ipsa illa duxisse abeuntemque praecepisse, si redisset ille, ostenderet adiceretque hnc esse quem quaereret, atque ita evenit. Revertit enim Apelles et vinci erubescens tertio colore lineas secuit nullum relinquens amplius subtilitati locum. At Protogenes victum se confessus in portu devolavit hospitem quaerens, placuitque sic eam tabulam posteris tradi omnium quidem, sed artificum praecipuo miraculo.

39 HIRST, Michael. Michelangelo and his drawings, New Haven-London, Yale University Press, 1988, pp. 16-21. 
devia muito de sua maniera à imitação das obras de Michelangelo.

A compreensão da destruição dos desenhos dentro do parâmentro dos discursos prescritivos e encomiásticos da arte do período nos permite supor uma segunda razão igualmente convincente para o gesto de Michelangelo: apresentar ao público suas invenções apenas depois de executadas com perfeição, em pintura ou em escultura ${ }^{40}$. Isto é o que diz Giorgio Vasari ao relacionar a destruição dos desenhos à grande quantidade de obras deixadas incompletas, ou apenas esboçadas, pelo artista:

\begin{abstract}
Tinha uma tal imaginativa e tão perfeita que as coisas propostas na idea eram tais que por não poder exprimir com as mãos tão grandes e terríveis conceitos, abandonou com frequência suas obras e destruiu muitas, como sei que, pouco antes de morrer, queimou um grande número de desenhos, esboços e cartões de sua mão, para ninguém visse as longas fadigas sofridas por ele e os modos de desafiar seu engenho para parecer perfeito. E tenho alguns desenhos de sua mão, encontrados em Florença, que foram colocados no nosso livro de desenhos, onde ainda se veja a grandeza daquele engenho, se conhece que quando queria tirar Minerva da cabeça de Júpiter, era necessário o martelo de Vulcano. ${ }^{41}$
\end{abstract}

40 BAMBACH. Ibidem, pp. 131-147.

41 VASARI. Ibidem, Vita di Michelagnolo Buonarroti, p, 1256: Ha avuto l'immaginitaiva tale e sì perfetta, che le cose propostosi nella idea sono state tali che con le mani, per non potere esprimere sì grande e terribile concetti, ha spesso abandonato l'opere sue, anzi ne ha guasto molte, come io so che, innanzi che morissi di poco, abruciò gran numero di disegni, schizzi e cartoni fatti di man sua, acciò nessuno vedessi le fatiche durate da lui et i modi di tentare l'ingegno suo, per non apparire se non perfetto, io ne ho alcuni di sua mano trovati in Fiorenza messi nel nostro libro de' disegni, dove ancora che vi vegga la grandezza di quello ingegno, si conosce che quando e' voleva cavar 
Benedetto Varchi, por sua vez, fornece um argumento filosófico para a preocupação do artista. No comentário que faz ao soneto de Michelangelo, Non ha l'ottimo artista alcun concetto, Varchi ressalta que a natureza produtiva da arte torna necessário que o artista coloque em ato a perfeita forma, o conceito, ou a ideia, imaginada, informando-a na matéria. Isto, de acordo com Varchi, não é outra coisa senão "reduzir à perfeição o que antes era imperfeito" 42 . Na Oração fúnebre, contudo, Varchi diz que os "esboços de Michelangelo na pintura e na escultura mostravam e mostram a profundidade de seu intelecto e de seu engenho; e maior estima tinham por eles que pelas obras de outros, ainda que perfeitas"43, vale dizer, acabadas.

Tanto mais dificultoso o conceito inventado, maior destreza no desenho e rapidez de mão é exigida do artista. Tratando da invenção do pintor, Holanda recomenda que o pintor ponha "velocíssima execução a sua idea e conceito, antes que alguma perturbação se lhe perca e deminua; e se ser podesse pôr-se com o stylo na mão e fazê-la com os olhos tapados, melhor seria, por não perder aquele divino furor e imagem que na fantesia leva" ${ }^{\prime 4}$. A passagem mais interessante a respeito desta qualidade artística

Minerva della testa di Giove, ci bisognava il martello di Vulcano...

42 VARCHI, Benedetto. 'Lezione prima sopra il sottoscritto sonetto di Michelagnolo Buonarotti. Fatta pubblicamente nella Accademia Fiorentina, la seconda Domenica di Quaresima, l'anno 1546', in Opere di Benedetto Varchi. Ora per la prima volta raccolte, vol. 2, Trieste, Lloyd Austriaco, 1859, pp. 615-616.

43 Idem. 'Orazione funerale', p. 28: gli schizzi di Michelangelo nella Pittura, e le bozze nella Scultura mostravano, e mostrano la profondità, ed excelência dell'intelletto, e ingegno suo; e maggiore stima si faceva di loro, che dell'Altrui opere, quantunque perfette.

44 HOLANDA. Ibidem, pp. 92-93. 
encontra-se no Terceiro Diálogo de Roma, porque nele Holanda coloca o próprio Michelangelo a prescrever a propósito da ligeireza de execução, dizendo que o perfeito artista

pintando depressa, não deixa por isso de pintar tão bem como o que pinta vagarosamente, merece por isso muito môr louvor. Mas se elle com a ligeireza da mão trespassa alguns lemites que não são licitos na arte trepassar, devia antes de pintar maes vagarosamente e studadamente; que não tem licença o excellente e valente home a se deixar ir enganando do gosto da sua presteza, quando se ella naguma parte se squece ou descuida do grande carrego da perfeição, que é a que sempre se ha de buscar. Onde não vem ser vicioso fazer um pouco de vagar, ou ainda, se comprir, muito, nem despender grande tempo e cuidado nas obras, se para maior perfeição se faz; mas sómente o não saber é defeito. ${ }^{45}$

Giovio é o primeiro a elogiar a rapidez de Michelangelo como virtude de sua perfeita arte. A pintura da Sistina, que o artista "completou em breve tempo", é para ele o "testemunho de uma arte perfeita". O mesmo elogio é feito às estátuas da Tumba de Júlio II, "as quais mereceram tanta admiração que se crê que nenhum artista depois dos antigos esculpiu o mármore com mais arte e rapidez que ele, nem pintou com mais harmonia e beleza" ${ }^{\prime 6}$.

45 HOLANDA. Ibidem, 'Terceiro diálogo', pp. 305-306.

46 GIOVIO. Ibidem, pp. 11-12: aliquot eius operis statuas praegrandes fecit, quae adeo probantur, ut nemo secundum veteres eo doctius atque celerius marmora scalpsisse, nemo commensuratius atque venustius pinxisse censeatur. 
Giovio transfere a Michelangelo as qualidades dos pintores antigos: a rapidez do pintor Nicômaco ${ }^{47}$ e a charis, ou a graça, da arte de Apeles $^{48}$. A velocidade de execução, contudo, não é uma virtude artística per se, já que, como notará Francisco de Holanda, a rapidez no artista desprovido de engenho e imperfeito no desenho é apenas fadiga inútil. Iguamente seu contrário, a excessiva diligência na execução, também não resulta em obra perfeita. A propósito deste vício, Plínio, o velho, conta que Apeles julgava o pintor Protógenes em tudo tão excelente quanto ele, exceto por "não saber tirar a mão do quadro, preceito memorável dos efeitos danosos da excessiva diligência" ${ }^{49}$.

Também o escultor Benvenuto Cellini, diz ter testemunhado Michelangelo esculpir um nu de grandeza natural em apenas sete dias, graças aos "furores admiráveis" que lhe ocorriam quando trabalhava $^{50}$. Como exige a perfeição de sua arte, a rapidez de

47 PLINIO, O VELHO. Ibidem, 108-111: nec fuit alius in arte velocior. Tradunt namque condixisse pingendum ab Aristrato, Sicyoniorum tyranno, quod is faciebat Telesti poetae monimentum praefinito die, intra quem perageretur nec multo ante venisse, tyranno in poenam accenso, paucisque diebus absolvisse et celeritate et arte mira.

48 Idem. Ibidem, XXXV, 79-80: precipua eius in arte venustas fuit, cum aedem aetate maximi pictores essent; quorum opera cum admiraretur, omnibus conlaudatis deesse illam suam venerem dicebat, quam Graeci charis vocant; cetera omnia contigisse, sed hac sola sibi neminem parem.

49 PLINIO, O VELHO. Ibidem, 80-81: et aliam gloriam usurpavit, cum Protogenis opus inmensi laboris ac curae supra modum anxiae miraretur; dixit enim omnia sibi cum illo paria esse aut illi meliora, sed uno se praestare, quod manum de tabula sciret tollere, memorabili praecepto nocere saepe nimiam diligentiam.

50 CELLINI, Benvenuto. 'Breve discorso intorno all'arte del Disegno, dove si conclude che la scultura prevaglia alla pittura, \& che migliori Architteti diveranno quegli che più perfetti scultori saranno, in Due Trattati, 
mão de Michelangelo é análoga ao furor de seu intelecto ${ }^{51}$. No capítulo nono, dedicado à invenção, do tratado De'Veri precetti della pittura, de 1586, Giovan Battista Armeni narra um episódio no qual Michelangelo, a pedido de um jovem oleiro que lhe havia prestado serviço, depois de considerar brevemente a sua invenção, executa, numa posição incômoda, como igual brevidade, um desenho de um Hércules em pé "tão bem traçado, sombreado e acabado", que parecia ter levado um mês para ser realizado ${ }^{52}$.

iintroduzione Antonio Altomonte, Modena, Edizioni Aldine, 1983, p. 47: Per l'essempio di Michelagnolo ci si rappresenta anchora quanto fusse la difficultà della scultura, essendo che egli conduceva un ignudo grande quant' il vivo con tutti i debitti studii che egli faceva nelle sue opere, in termine di sette giorni, $\&$ à me occorse di vedere tal'hora che la mattina alla sera egli haveva finito un ignudo con le diligenze che l'arte permette. Mano ne ristringendomi a tempo così breve; percioche molte volte egl'era tratto da certi furori mirabili che nel lavorare gli venivano.

51 A própósito da rapidez e da dificuldade da arte de Michelangelo cf. CLEMENTS, Robert J. 'Michelangelo on effort and Rapidity in art', in Journal of Warburg and Courtauld Institutes, vol. 17, n. 3/4, 1954, pp. 301-310.

52 ARMENINI, Giovan Battista. De'veri precetti della pittura, Torino, Einaudi, 1988, p. 92-93: Ma il modo di Michel Angelo, così a gli altri difficile, a lui fu molto agevole, quantunque diverso e novo per le artifizioze attitudini, che si mostra delle sue figure, sí come dall'ottimo suo rilievo tutte imitate, della facilità del quale io ne viddi una volta in Roma mirabil prova, se bene egli fu di poca cosa. Conciosiaché un dí, essendo egli dietro la chiesa di San Pietro, s'incontrò in un giovane ferrarese vasaro, il qual, ringraziato da Michel Angelo di non so che lavoro di terra, il qual gli aveva fatto cuocere, li sogiunse dipoi che alui comandasse, che volentieri lo servirebbe. Il giovene, cosí assicurato dalle parole di un uomo tale, li portò un foglio di carta e lo pregò che suso li dissegnasse un Ercole in piedi. Allora prese Michel Angelo quella carta e tiratosi da parte sotto in picciol tetto che ivi era, dove era un scanno da sedervi, sul tale postovi su il piè destro et il gomito su ginocchio alto, poggiatosi la mano al viso si stette pensoso un poco; dipoi si mise a disegnar quello, il qual, finito in breve tempo, acennò al giovene, che vi era poco di lunge, che egli 
Retornando à topica relativa ao caráter de Michelangelo, observa-se que a relação de proporção estabelecida por Giovio entre a terribilità de seu caráter e a dificuldade de sua maneira, será amplificada nos encômios posteriores. O aspecto "selvagem" e "rude" de seu caráter será reinterpretado como uma licença exigida tanto pelo engenho divino e terribile do artista, quanto pelo amor e diligência que devotou à prática da arte. De acordo com Giorgio Vasari

Não é novidade para ninguém que Michelangelo se deleitasse com a solidão como alguém que é enamorado da sua arte, que quer o homem, cogitativo, todo para si, porque quem quer se ocupar dos estudos da arte deve fugir às companhias. Quem se ocupa das considerações da arte nunca está só, nem sem pensamentos e aqueles que atribuem isto a devaneios e estranhezas estão errados porque quem quer operar bem precisa se afastar de todos os cuidados e fastídios, porque a virtude quer o pensamento, a solidão e a comodidade, e não o divagar com a mente. ${ }^{53}$

venisse inanzi e così glielo porse e via si dipartí et andossene verso palazzo. Il qual dissegno, per quanto io conosceva allora, mi parve così ben lineato, ombrato e finito, che passava ogni uso di minio et era un stupor grande a quelli che ciò aveano veduto fare in così poco tempo, che altri vi averebbe giudicato dentro la fatica di un mese, sì che si può fare questo giudizio quanto gli doveva essere facile in far le sue invenzioni.

53 VASARI. Ibidem. 'Vita di Michelagnolo Buonarroti', p. 1256: Né paia nuovo a nessuno che Michelagnolo si diletassi della solitudine, come quello che era innamorato dell'arte sua, che vuol l'uomo per se solo e cogitativo e perché è necessario che, chi attendere agli studii di quella fugga le compagnie: avenga che chi attende alle condiderazioni dell'arte non è mai solo né senza pensieri, e coloro che gliele attribuivano a fantasticheria et a stranezza, hanno il torto perché chi vuole operar bene, bisogna allontanarsi da tutte le cure e fastidi, perché la virtù vuol pensamento, solitudine e comodità, e non errare con la mente. 
Assim como já havia feito Ascânio Condivi e Francisco de Holanda, o retrato que Vasari e Benedetto Varchi compõem do caráter de Michelangelo não apenas o defende da crítica de Giovio, mas encarece nele as demais virtudes obrigatórias nos engenhos excelentes, cujo modelo é o do orador: ser versado nas várias ciências e artes, ser virtuoso, honesto, magnânimo, liberal, mas sobretudo, ter nascido agraciado com um engenho excepcional. $\mathrm{Na}$ primeira versão da Vita de Michelangelo, Vasari que

o bondoso Reitor do céu dirigiu seus olhos clemente para a terra, e vendo a vã infinidade de tantas fadigas, os dedicados estudos sem nenhum fruto e a opinião presunçosa dos homens, tão distante da verdade quanto as trevas da luz, para nos retirar de tantos erros se dispôs a enviar à terra um espírito que fosse hábil, universalmente, em todas as artes e profissões, e operasse por si só para mostrar quais eram as dificuldades na ciência das linhas, na pintura, no juízo da escultura e na invenção da deleitável arquitetura. E quis, além disso, que viesse acompanhado da verdadeira filosofia moral, com o ornamento da poesia, até que o mundo o elegesse e o admirasse, através de seu singular espelho, na vida, nas obras, na saúde dos costumes e em todas as ações humanas, e que este isto fosse nomeado por nós coisa mais celeste que terrena. ${ }^{54}$

No primeiro dos quatro Diálogos de Roma, de Francisco de Holanda, é Michelangelo quem defende os pintores e a si próprio das acusações de falta de urbanidade e soberba, de ser fantasiosos

54 VASARI. Vite de'più eccellenti architteti, pittori, et scultori italiani, da Cimabue, insino a'tempi nostri (edizione Torrentiniana 1550), Torino, Einaudi, p. 880. 
e de "conversação dura", retratando positivamente o que seriam vícios no comportamento de um cortesão como virtudes do temperamento melancólico dos pintores eminentes e perfeitos:

Há muitos que afirmam mil mentiras, e uma é dizer que os pintores eminentes são estranhos e de conversação incomportabel e dura, sendo elles de humana condição. E assi os nesceos e não os moderados os julgam fantasticos e fantesiosos, sofrendo com grande deficuldade taes condições num pintor. É bem verdade que taes condições num pintor não se acham senão onde ha o pintor, que é em poucas partes, como em Italia, onde ha a perfeição das cousas. Mas não tem grande razão os imperfeitos ociosos, que de um ocupado perfeito querem tantos comprimentos, havendo poucos mortaes que façam bem seu officio; nem o faz nenhum d'aquelles que acusa a quem faz o seu. Que os valentes pintores não são em alguma maneira desconversaveis, por soberba, mas ou porque acham poucos engenhos dinos da pintura, ou por não corromperem com a inutel conversação dos ociosos e abaxarem o intelecto das continuas e altas imaginações de que sempre andam embelesados. E affirmo a V. Ex.a que até a Sua Santidade me dá nojo e fastio quando me ás vezes falla e tão pesantemente pregunta porque não o vejo; e ás vezes cuido que o sirvo mais em não ir ao seu chamado, querendo-me pouco, que quando o eu quero em minha casa servir em muito; e lhe digo que então o sirvo mais como M. Angelo, que stando todo o dia diante d'elle em pé como outros. ${ }^{55}$

55 HOLANDA. Ibidem, 'Primeiro diálogo', p. 230-231. 
Na carta datada de 15 de novembro de 1520 , Sebastiano del Piombo relata a Michelangelo a conversa que teve com o papa Leão X, na qual o papa reconhece tanto a qualidade da maneira de Michelangelo, à qual todos artistas, inclusive Rafael, passaram a imitar, quanto o seu temperamento terribile, que impossibilitava qualquer conversação. O relato de Sebastiano inclui a defesa que ele próprio faz do amigo, dizendo ao papa que tal terribilità devia-se ao amor que Michelangelo tinha pelas grandes obras:

Eu the respondi que, com a vossa ajuda me bastaria ânimo de fazer milagres. E ele me respondeu: 'Não duvido disto, porque todos vós aprenderam com ele'. E pela confiança que há enre nós, Sua Santidade me disse: 'Olhe as obras de Rafael, porque depois que viu as obras de Michelangelo deixou de pronto a maneira de Perugino e se aproximou o quanto pôde àquela de Michelangelo. Mas, é terrível como vedes: não se pode conversar com ele'. E respondi a Sua Santidade, que a vossa terribilidade não feria ninguém e que pareceis terrível por amor que tinha pela importância das grandes obras e por outras razões que não ocorrem dizer, porque não importam..$^{56}$

56 MICHELANGELO. Carteggio, II, pp. 246-247: Et io li resposi che, con l'aiuto vostro, a me basteria l'animo de far miracoli. Et lui me rispose 'Non dubito di questo, perché tutti vui havete imparato da lui'. Et, per la fede è tra nui, Sua Santità me disse più 'Guarda l'opere de Rafaelo, che come vide le hopere de Michelagniolo, subito lassò la maniera del Perosino et quanto più poteva si acostava a quella de Michelagnolo. Ma è teribile, come tu vedi; non si pol pratichar con lui'. Et io resposi a Sua Santità che la teribelità vostra non noceva a persona, et che vui parete terribile per amor de l'importantia de l'opere grande havete, et altri rasonamenti che non accade a scriver, ché non importa. 
Não faltou aos encômios a Michelangelo o encarecimento das amizades que manteve com pessoas virtuosas, entre eles, o poeta Poliziano, Vittoria Colonna, os humanistas Latanzio Tolomei, Annibale Caro, Donato Giannotti e o próprio Benedetto Varchi. Superando o antigo Apeles, que manteve com Alexandre, o grande, uma relação de respeito e amizade, Michelangelo não apenas privou, mas foi disputado por cinco papas e vários príncipes. Esta é a maior prova de grandeza que um artista pode ostentar em vida, como nota Varchi quando diz: "ouçam, ouçam nobres e agudos Ouvintes, e julguem por isso quem fosse Buonarroti, e quanto podem as virtudes nos ânimos nobres" ${ }^{97}$. Também a propósito deste privilégio, Ascanio Condivi diz:

que maior sinal e mais claro pode haver da excelência deste homem [Michelangelo] do que a contenda que fizeram os príncipes para tê-lo?[...] Estas não são coisas ordinárias, que ocorrem todos os dias, mas novas e fora do comum, tampouco costumam ocorrer senão em virtudes singulares e excelentes como aquela de Homero, disputado por muitas cidades, cada uma usurpando-o e fazendo-o seu ${ }^{58}$.

Por fim, a última e maior evidência da grandeza e da

57 VARCHI. 'Orazione funerale', p. 44: Ma che bisogna, che io vada tra la genti barbare, tra popoli infedeli, e nazioni lontanissime per dimostrare menomissima parte degl'honori del Buonarroto? Udite, udite nobilissimi, e acutissimi Ascoltatori, e giudicate tra voi da questo e chi fosse il Buonarroto, e quanto possanza habbiano le virtù ne gli animi nobili.

58 CONDIVI. Ibidem, p.149: Ma che segno maggiore e più chiaro può mai essere della eccellenza di quest'uomo, che la contenzione che hanno fatta I principi del mondo per averlo? 
dignidade de Michelangelo é a sua boa morte. Benedetto Varchi encerra sua Oração fúnebre, encarecendo a morte beata e feliz do artista, que morreu em idade avançada, aos 86 anos: "Michelangelo conseguiu na morte sua última perfeição, sua última felicidade e sua última beatitude". A morte de Michelangelo, que "foi produzido no céu, e mandado à terra por Deus não como simples homem, mas como monstro altivo e novo milagre dos homens" ${ }^{59}$, não poderia ser senão indício do declínio da excelência nas artes:

“onde não podendo por eterna e imutável lei de Deus e da Natureza as coisas mundanas e transitórias durar longamente em um mesmo estado, é necessário que começem a declinar e entrar em colapso: e queira Deus que até agora não tenham começado" ${ }^{60}$.

Se Michelangelo continua a ser considerado um dos "gênios" da arte ocidental, é porque os elogios tecidos pelos autores do século XVI foram eficazes em seu objetivo: produzir a fama e a glória que consideravam obrigatórias aos homens virtuosos, dotados de engenho excepcional e capazes de executar ações e obras dignas de memória. Contra elas, fracassaram tanto as críticas contrareformistas à falta de decoro de seus nus nos afrescos do Juízo Final, devidamente censurados após sua morte, quanto o progressivo desinteresse, a partir do século XVIII, por sua maneira terribile.

59 VARCHI. 'Orazione funerale', p. 56: Michelangelo esse stato prodotto in cielo, e mandato in terra da Dio non per huomo semplicemente, ma per altero mostro, e nuovo miracolo degl'huomini.

60 Idem. Ibidem, p. 57: La onde non potendo per eterna, e incommutabile legge di Dio, e della natura durare queste cose mundane, e transitorie in uno stato medesimo lungamente, è necessário, che elle comincino à declinare, e dare il tracollo: e voglia Dio che elleno infino à quest'hora incomminciato non habbiano. 


\section{Referência bibliográfica}

BAMBACH, Carmen C. "Vasari on Michelangelo's "Gelosie delle Figure" and the destruction of his drawings', in Annali Aretini XX, Edizioni Fraternità dei Laici Arezzo, 2012, pp. 131-147.

CICERO. Orator, translated by G. L. Hendrickson e H. M. Hubbell, Loeb Classical Library, Cambridge-London, Harvard University Press, 1939.

Codice Magliabechiano, C1 XVII, 17, contenente notizie sopra l'arte degli Antichi e quella de'fiorentini da Cimabue a Michelangelo Buonarroti, org. Carl Frey, Berlin, G. Grote'sche Verlagsbuchandlung, 1892.

CLEMENTS, Robert J. 'Michelangelo on effort and Rapidity in art', in Journal of Warburg and Courtauld Institutes, vol. 17, n. 3/4, 1954.

CONDIVI, Ascanio. Vita di Michelangelo (1553) Roma, De Luca Editore, 1964.

GIANOTTI, Donato. Dialoghi de'giorni che Dante consumo nel cercare l'inferno e l'Purgatorio, 1549, org. Diocletio Redig de Campos, Firenze, Sansoni, 1939.

GIOVIO, Paolo. 'Michaelis Angeli Vita', in BAROCCHI, Paola. Scritti d'arte del Cinquecento, tomo I, Milano-Napoli, Riccardo Ricciardi, 1971.

HIRST, Michael. Michelangelo and his drawings, New Haven-London, Yale University Press, 1988.

HOLANDA, Francisco. Da Pintura Antiga, introdução e notas Angel González-Garcia, Lisboa, Imprensa Nacional-Casa da Moeda, 1983. 
Limiar - vol. $2, \mathrm{n}^{\mathrm{o}} 3-2^{\circ}$ semestre 2014

KENT, D. Friendship, Love, and trust in Renaissance Florence (The Bernard Berenson lectures at Villa I Tatti, Harvard University Center for Italian Studies), Cambridge-London, I Tatti Harvard University Press, 2009.

MANETTI, Gianozzo. Biographical writings, editado e traduzido por Stefano U. Baldassari e Rolf Bagelmihl, The I Tatti Renaissance Library, Harvard University Press, 2003.

MiCHELANGELO. Carteggio, a cura di Paola Barocchi, Firenze, S.P.E.S.,1967-1985.

PARKER, Deborah. Michelangelo and the Art of Letter Writing, Cambridge University Press, 2010.

PINO, Paolo. Dialogo di Pittura (1548), in BAROCCHI, Paola. Scritti d'arte del cinquecento, I, Milano/Napoli, Riccardo Ricciardi, 1971.

PLINIO, O VELHO. Natural History XXXV, translated by H. Rackham, Loeb Classical Library, Cambridge-London, Harvard University Press, 1952.

POZZI, Mario \& MATTIODA, Enrico. Giorgio Vasari. Storico e critico, Firenze, Leo Olschki Editore, 2006.

QUINTILIANO. Instituto Oratoria, translated by H. E. Butler, Loeb Classica Library, Cambridge-London, Harvard University Press, 1933.

SCHLOSSER MAGNINO, Julius. La letteratura artistica. Manuale delle fonti della storia dell'arte moderna, Firenze, La Nuova Italia, 1996.

SUMMERS, David. Michelangelo and the language of Art, Princeton, Princeton University Press, 1981. 
VARCHI, Benedetto. 'Lezione prima sopra il sottoscritto sonetto di Michelagnolo Buonarotti. Fatta pubblicamente nella Accademia Fiorentina, la seconda Domenica di Quaresima, l'anno 1546', in Opere di Benedetto Varchi. Ora per la prima volta raccolte, vol. 2, Trieste, Lloyd Austriaco, 1859.

VARCHI, Benedetto. 'Orazione funerale di Messer Benedetto Varchi fatta, e recitata da lui pubblicamente nell'essequie di Michelagnolo Buonarroti in Firenze nella chiesa di San Lorenzo', Firenze, Giunti, 1564, editada e comentada por Charles Davis, in Quellen und Dokumente zur Kunst 1350-1750, E- Texte, n. 23 http://archiv.ub.uni-heidelberg.de/artdok/volltexte/2008/643

VASARI, Giorgio. Vite de'più eccellenti architteti, pittori, et scultori italiani, da Cimabue, insino a' tempi nostri (edizione Torrentiniana1550), a cura di Liciano Bellosi e Aldo Rossi, Torino, Einaudi, 1986.

VASARI, Giorgio. Le Vite dei più eccellenti pittori, scultori e architetti (edizione Giuntina 1568), Roma, Edizione Newton, 1991.

VENTURI, Lionello. História da crítica de arte, primeira edição, 1936, Lisboa, Edições 70, 2007. 